Article

\title{
Serum Levels of MicroRNA-206 and Novel Mini-STR Assays for Carrier Detection in Duchenne Muscular Dystrophy
}

\author{
Mónica Alejandra Anaya-Segura ${ }^{1,2}$, Héctor Rangel-Villalobos ${ }^{3}$, Gabriela Martínez-Cortés ${ }^{3}$, \\ Benjamín Gómez-Díaz ${ }^{4}$, Ramón Mauricio Coral-Vázquez ${ }^{5}$, Edgar Oswaldo Zamora-González ${ }^{6}$, \\ Silvia García ${ }^{7}$ and Luz Berenice López-Hernández ${ }^{8, *}$ \\ 1 Center for Research and Assistance in Technology and Design of the State of Jalisco (CIATEJ, A.C.), \\ Guadalajara 44270, Mexico; monica207383614@gmail.com \\ 2 Asociación de Distrofia Muscular de Occidente A.C., Guadalajara 44380, Mexico \\ 3 Centro Universitario de la Ciénega, Universidad de Guadalajara, Ocotlán 47820, Mexico; \\ hrangel@cuci.udg.mx (H.R.-V.); gaby_ed15@yahoo.com.mx (G.M.-C.) \\ 4 National Center for Research and Care in Sports Medicine, National Institute of Rehabilitation, \\ México City 14389, Mexico; bngomez@inr.gob.mx \\ 5 Section of Postgraduate Studies and Research, Superior School of Medicine, National Polytechnic Institute, \\ México City 11340, Mexico; rcoral@ipn.mx \\ 6 Centro Universitario del Norte, Universidad de Guadalajara, Colotlán 46200, Mexico; \\ edgar.zamora@cunorte.udg.mx \\ 7 Servicio de Investigación Clínica, Centro Médico Nacional “20 de Noviembre”, Instituto de Seguridad y \\ Servicios Sociales de los Trabajadores del Estado, México City 03100, Mexico; rolasil@yahoo.com.mx \\ 8 División de Investigación Biomédica, Centro Médico Nacional “20 de Noviembre”, \\ Instituto de Seguridad y Servicios Sociales de los Trabajadores del Estado, México City 03100, Mexico \\ * Correspondence: lblhmedgen@gmail.com or luz.lopezhe@issste.gob.mx; \\ Tel.: +52-55-5200-5003; Fax: +52-33-3632-6200
}

Academic Editor: William Chi-shing Cho

Received: 3 May 2016; Accepted: 1 August 2016; Published: 13 August 2016

\begin{abstract}
Duchenne Muscular Dystrophy (DMD) is an X-linked neuromuscular disorder in which the detection of female carriers is of the utmost importance for genetic counseling. Haplotyping with polymorphic markers and quantitation of creatine kinase levels (CK) allow tracking of the at-risk haplotype and evidence muscle damage, respectively. Such approaches are useful for carrier detection in cases of unknown mutations. The lack of informative markers and the inaccuracy of CK affect carrier detection. Therefore, herein we designed novel mini-STR (Short Tandem Repeats) assays to amplify 10 loci within the DMD gene and estimated allele frequencies and the polymorphism information content among other parameters in 337 unrelated individuals from three Mexican populations. In addition, we tested the utility of the assays for carrier detection in three families. Moreover, given that serum levels of miR-206 discern between DMD patients and controls with a high area under the curve (AUC), the potential applicability for carrier detection was assessed. The serum levels of miR-206 of non-carriers $(n=24)$ and carriers $(n=23)$ were compared by relative quantitation using real-time PCR $(p<0.05)$, which resulted in an AUC $=0.80$ in the Receiver Operating Characteristic curve analysis. In conclusion, miR-206 has potential as a "liquid biopsy" for carrier detection and genetic counseling in DMD.
\end{abstract}

Keywords: microRNA-206; mini-STR; carrier detection; DMD; liquid biopsy 


\section{Introduction}

Pathogenic variants within the DMD cause a spectrum of recognizable phenotypes known as dystrophinopathies. Duchenne Muscular Dystrophy (DMD) is the most severe and affects male newborns in almost all cases [1]; since it is an X-linked recessive disorder, carrier detection is of the utmost importance for genetic counseling. Female relatives require genetic testing and genetic counseling to avoid the birth of affected children without enough knowledge of the disease to make informed decisions [2]. In addition, manifestations of dystrophinopathies are present in a range of $8 \%-40 \%$ of heterozygous females, and this affects their life quality [3,4]. About $8 \%$ of them manifest clinically relevant features of the disease such as abnormal gait, calf hypertrophy, cardiomyopathy, cramps, exercise intolerance, and intellectual and learning disabilities, among other signs and symptoms [5].

Therefore, the Muscular Dystrophy Surveillance Tracking and Research Network (MD STARnet) has established clinical guidelines to support definite diagnosis. A definite case of dystrophinopathy should be pursued prior to carrier detection. Precise diagnosis requires a combination of clinical data, family history (FH), creatine kinase (CK) levels, genetic analysis (direct/indirect) [2], and in some cases, immunostaining of muscle biopsies [6]. Consequently, genetic counseling for at-risk females and prenatal diagnosis remain challenging for cases in which deep intronic mutations in the DMD are difficult to detect even with next-generation sequencing which often covers only exonic regions $[7,8]$. Indirect tracking of the haplotype that co-segregates with the disease within a family is required in those cases [2,6]. For that reason, improvements in the integration of data derived from segregation analyses with informative DNA markers such as short tandem repeats (STRs) or single nucleotide polymorphisms (SNPs), the measurement of serum biomarkers such as $\mathrm{CK}$ and the consideration of familiar structure allow reliable calculation of recurrence risks with specialized software such as RiscalW [8]. However, limitations of such approaches are: (1) Low heterozygosity affects segregation analysis, since the detection of different alleles between affected and unaffected males allows the indirect detection of the at-risk haplotype. Thus, the number of alleles and their frequency within a population are relevant parameters that affect carrier detection using indirect analysis and haplotyping; (2) Degraded DNA samples are challenging to amplify with conventional amplicons [9]; (3) CK levels are not optimal biomarkers for carrier detection (diagnostic efficiency $=50 \%$ ) [10]. Therefore, exploration of alternative non-invasive biomarkers for carrier detection and the use of optimized multiplex amplicons represent an attractive option that may in turn outperform the above mentioned approaches. In this regard, it was recently shown that a small group of microRNAs called "dystromirs" miR-1, miR-133, and miR-206 are valuable diagnostic biomarkers for DMD because they are able to distinguish among DMD and non-affected males; in particular, the skeletal muscle-specific miR-206 is upregulated in satellite cells following muscle injury [11,12]. Interestingly, miR-206 showed higher AUCs (Area Under the Curve) to differentiate not only DMD vs. normal individuals, but also Becker Muscular Dystrophy (BMD) (a less severe type of dystrophinopathy) [11] and DMD phenotypes compared to the other microRNAs. Hence, since female DMD carriers may have subclinical muscle involvement [13], quantitation of serum levels of miR-206 may harbor potential for carrier detection. For that reason, the aims of this work were the following: (1) designing novel mini-STR assays and estimating the polymorphic information content (PIC) values in three Mexican populations; (2) performing haplotype analysis in DMD families; and (3) testing differences in serum levels of miR-206 between healthy females and DMD carriers to test its diagnostic potential for carrier detection. Cell-free nucleic acids, which include cell-free DNA, cell-free mRNA, and circulating miRNAs, are being explored for various clinical applications, such as "liquid biopsy" and "non-invasive prenatal testing" (NIPT) [14]. The approaches presented herein harbor high potential to extend the above-mentioned clinical applications for carried detection in DMD. 


\section{Results}

\subsection{Population Analysis}

Most present-day Mexicans denominated "mestizos" as a population group, are the result of the ancestral admixture of different populations (Europeans, Amerindians and Africans). This process did not occur equally through all the geographical regions of Mexico; such heterogeneity in allele frequencies prevails nowadays [15]. This fact should be considered for genetic studies aimed at detecting candidate genes for medical traits as well as for applications of genetic variations such as the use of STRs for the detection of the at-risk haplotypes in DMD [16]. Therefore, genetic diversity was analyzed based on allele frequencies of 10 STRs within the DMD in the three Mexican population samples (Table 1); for instance, 15 alleles were found for the $5^{\prime}-5 \mathrm{n} 4$ marker (Figure 1C). The markers presented a wide diversity of alleles, where at least four alleles were found for DXS1234 and up to 15 were found for DI623 (Table 1). The north region was in Hardy-Weinberg equilibrium (HWE) for all the analyzed loci, whereas the west and southeast regions presented HWE deviations $(p<0.05)$ for DXS1237, 5'-7n4 and DXS1234, DXS1237, and 5'-5n4 markers, respectively (Table 1). However, after applying the Bonferroni correction these deviations were not significant $(p>0.005)$.

On the other hand, an indicator of the utility of the STRs for segregation analysis is the PIC value; which defines the expected fraction of informative offspring from one particular type of human pedigree (Table 2). Interestingly, although in most cases PIC values were similar between the studied populations, the north region showed elevated values in all STR loci (PIC > 0.60). PIC values observed for the 10 STRs in the three Mexican populations ranged from 0.52 to 0.88 , whereas DXS1236 and DI623 were the most informative markers with more alleles (Table 1). Although in other populations similar PIC values were observed with respect to the Mexican regions studied herein, some differences were noticed as indicated in Table 2.

Table 1. Estimation of genetic diversity and Hardy-Weinberg equilibrium in the three populations studied.

\begin{tabular}{|c|c|c|c|c|c|c|c|c|c|c|c|c|}
\hline \multirow[b]{2}{*}{ STR loci } & \multicolumn{4}{|l|}{ North } & \multicolumn{4}{|l|}{ West } & \multicolumn{4}{|c|}{ Southeast } \\
\hline & $\mathbf{H}_{\mathrm{E}}$ & $\mathbf{H}_{\mathrm{O}}$ & $\mathbf{N}_{\mathrm{A}}$ & $\begin{array}{l}\text { HWE } \\
p \text {-Value }\end{array}$ & $\mathrm{H}_{\mathrm{E}}$ & $\mathrm{H}_{\mathrm{O}}$ & $\mathbf{N}_{\mathrm{A}}$ & $\begin{array}{l}\text { HWE } \\
p \text {-Value }\end{array}$ & $\mathbf{H}_{\mathrm{E}}$ & $\mathbf{H}_{\mathrm{O}}$ & $\mathbf{N}_{\mathbf{A}}$ & $\begin{array}{l}\text { HWE } \\
p \text {-Value }\end{array}$ \\
\hline DXS1242 & 0.765 & 0.722 & 8 & 0.5349 & 0.742 & 0.576 & 8 & 0.0581 & 0.713 & 0.848 & 8 & 0.1857 \\
\hline $5^{\prime}-5 n 4$ & 0.751 & 0.786 & 12 & 0.9521 & 0.763 & 0.720 & 13 & 0.1182 & 0.578 & 0.442 & 9 & 0.0419 \\
\hline $5^{\prime}-7 \mathrm{n} 4$ & 0.508 & 0.529 & 5 & 1.0000 & 0.665 & 0.833 & 7 & 0.0127 & 0.566 & 0.769 & 6 & 0.3488 \\
\hline DXSDMD-In30 & 0.500 & 0.500 & 5 & 1.0000 & 0.503 & 0.423 & 5 & 0.4792 & 0.505 & 0.396 & 7 & 0.1583 \\
\hline DXS1237 & 0.815 & 0.615 & 9 & 0.2737 & 0.754 & 0.500 & 10 & 0.0141 & 0.723 & 0.578 & 11 & 0.0229 \\
\hline DXS997 & 0.575 & 0.750 & 5 & 0.2965 & 0.475 & 0.389 & 6 & 0.3778 & 0.373 & 0.333 & 6 & 0.1780 \\
\hline DXS1236 & 0.862 & 0.889 & 14 & 0.9764 & 0.800 & 0.969 & 13 & 0.9764 & 0.809 & 0.909 & 14 & 0.9764 \\
\hline DXSDMD-In60 & 0.652 & 0.667 & 7 & 0.4278 & 0.613 & 0.500 & 7 & 0.4278 & 0.647 & 0.627 & 8 & 0.4278 \\
\hline DI623 & 0.766 & 0.647 & 14 & 0.6746 & 0.776 & 0.613 & 13 & 0.2555 & 0.746 & 0.791 & 15 & 0.6673 \\
\hline DXS1234 & 0.675 & 0.389 & 6 & 0.0931 & 0.467 & 0.406 & 4 & 0.1117 & 0.539 & 0.290 & 5 & 0.0109 \\
\hline
\end{tabular}


Table 2. Comparison of polymorphism information content (PIC) of the 10 STRs in different populations.

\begin{tabular}{|c|c|c|c|c|c|c|}
\hline \multirow{2}{*}{ STR loci } & \multicolumn{3}{|c|}{ Mexico } & \multirow{2}{*}{\multicolumn{2}{|c|}{ Other Populations }} & \multirow{2}{*}{ Reference } \\
\hline & North & West & Southeast & & & \\
\hline DXS1242 & 0.77 & 0.80 & 0.70 & 0.77 & USA & [17] \\
\hline $5^{\prime}-5 n 4$ & 0.73 & 0.78 & 0.58 & 0.64 & New Zealand & [18] \\
\hline $5^{\prime}-7 \mathrm{n} 4$ & 0.62 & 0.69 & 0.62 & 0.52 & New Zealand & [18] \\
\hline DXSDMD-In30 & 0.61 & 0.56 & 0.63 & 0.65 & China & [19] \\
\hline DXS1237 & 0.82 & 0.78 & 0.73 & 0.89 & USA & [20] \\
\hline DXS997 & 0.67 & 0.58 & 0.53 & 0.70 & France & [21] \\
\hline DXS1236 & 0.88 & 0.87 & 0.88 & 0.93 & USA & [20] \\
\hline DXSDMD-In60 & 0.76 & 0.77 & 0.77 & 0.69 & China & [19] \\
\hline DI623 & 0.88 & 0.87 & 0.87 & 0.91 & Japan & [22] \\
\hline DXS1234 & 0.74 & 0.52 & 0.55 & 0.34 & Japan & [22] \\
\hline
\end{tabular}

A) Short Tandem Repeat map

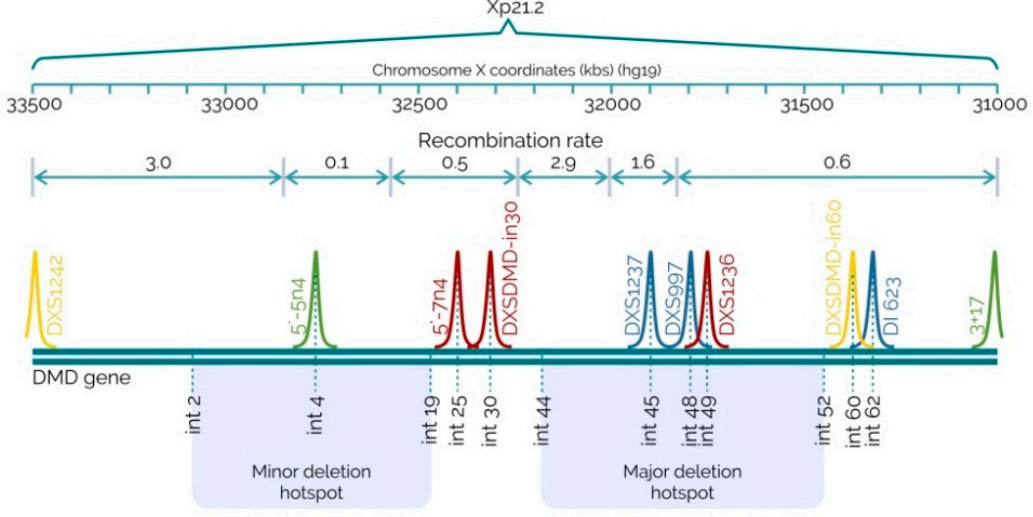

B) Multiplex amplification

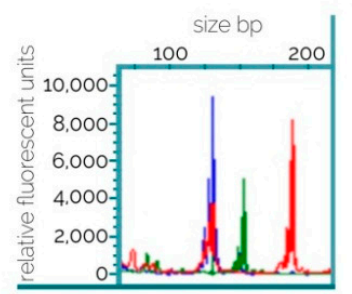

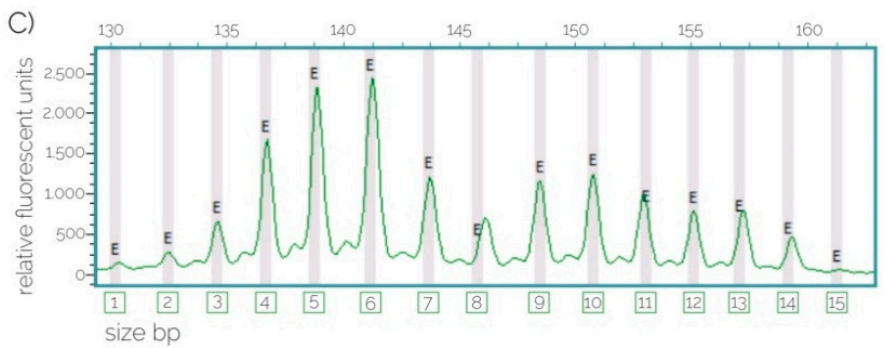

D)

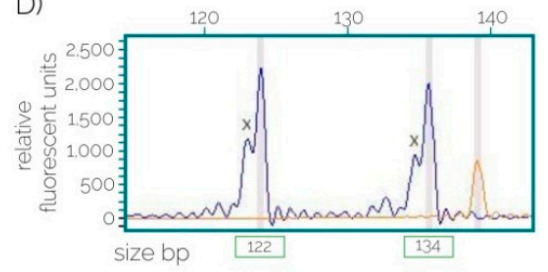

Figure 1. Mini-STR assays. (A) Simplified map of the DMD gene showing the location of the 10 intragenic mini-STRs, which are evenly distributed to cover the DMD gene from the $5^{\prime}$ to $3^{\prime}$ regions, markers are depicted with their corresponding labeled primers: NED (yellow), PET (red), VIC (green), or FAM (blue); (B) Amplification of one of our novel mini-STR assays. Differentially labeled primers allow the analysis of different targets in the same channel; (C) Genetic diversity was analyzed based on allele frequencies of 10 STRs in the three Mexican population samples (Table 1); for instance, a total of 15 different alleles were detected for the 5'-5n4 marker in these population samples; (D) Example of the genotype of a female for the marker DI623.

\subsection{STRs for Carrier Detection}

Seven females belonging to three unrelated families requested the result of the genetic testing derived from our research study (Table 3), and their samples were used to perform an indirect haplotype analysis. While half of the analyzed markers were conclusive for two families, seven STRs were conclusive for the remaining. The DXS1236, DI623 and DXSDMD-In30 markers were determinant in all three families, even when DXSDMD-In30 showed a PIC smaller than 0.5. The markers 5'-5n4, 
$5^{\prime}-7 \mathrm{n} 4$ and DXS1237 were determinant in the first two cases, and DXSDMD-In60 was determinant exclusively in case number 3. One female carrier was detected (Figures 1D and 2), while the remaining six were not carriers (Table 3).

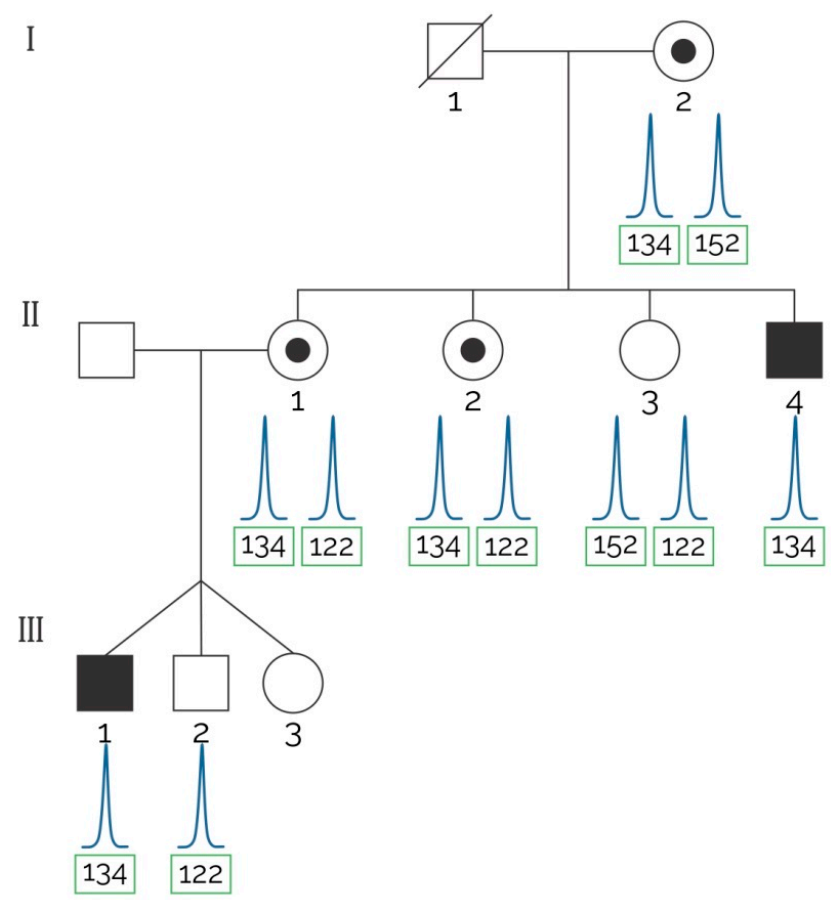

Figure 2. Segregation analysis in a pedigree with family history of the disease.

Table 3. Application of the STR assays in Mexican families. Family History (FH), Multiplex Ligation Dependent Probe Amplification (MLPA).

\begin{tabular}{|c|c|c|c|}
\hline Family & Case Description & $\begin{array}{l}\text { Applicability of STRs Indirect } \\
\text { Haplotyping Analysis }\end{array}$ & Concluding Remarks \\
\hline 1 & $\begin{array}{l}\text { Three sisters of an index case with } \\
\text { positive FH and two male children } \\
\text { (triplets) were tested by MLPA and } \\
\text { the assay proposed herein to detect } \\
\text { the at-risk haplotype (see Figure 2). }\end{array}$ & $\begin{array}{l}\text { Informative markers: } \\
\text { 5'5n4, DXSDMD-In30, DXS1237, } \\
\text { DXS1236, DI623. }\end{array}$ & $\begin{array}{c}\text { MLPA confirmed a deletion of exons } \\
6-7 \text { that segregated with the at-risk haplotype } \\
\text { traced with our assay. Two out of three } \\
\text { sisters of the index case were carriers } \\
\text { of the at-risk haplotype. }\end{array}$ \\
\hline 2 & $\begin{array}{l}\text { Two aunts of an index case with } \\
\text { positive FH in which a mutation } \\
\text { was not found after MLPA analysis } \\
\text { solicited genetic testing. }\end{array}$ & $\begin{array}{l}\text { Informative markers: } \\
\text { 5'-5n4, 5'-7n4, DXSDMD-In30, } \\
\text { DXS1236, DI623. }\end{array}$ & $\begin{array}{l}\text { Both analyzed females were non-carriers of } \\
\text { the at-risk haplotype; all the obligate carriers } \\
\text { shared the at-risk haplotype } \\
\text { found in the index case. }\end{array}$ \\
\hline 3 & $\begin{array}{l}\text { Three aunts of an index case with } \\
\text { positive FH in which a mutation } \\
\text { was not found after MLPA analysis } \\
\text { solicited genetic testing. }\end{array}$ & $\begin{array}{l}\text { Informative markers: } \\
\text { DXS1242, 5'-7n4, DXS1237, } \\
\text { DXS1236, DXSDMD-In60, } \\
\text { DXSDMD-In30, DI623. }\end{array}$ & $\begin{array}{l}\text { None of the analyzed females were carriers of } \\
\text { the at-risk haplotype. Next-generation } \\
\text { sequencing confirmed that a point mutation } \\
\text { (stop codon) in exon } 30 \text { co-segregated with } \\
\text { the at-risk haplotype. }\end{array}$ \\
\hline
\end{tabular}

The DI623 marker was used in a DMD case (index case II-4) with a positive family history (Figure 1D). Three sisters of the index case (II-1, II-2 and II-3) were tested and compared to the grandmother (I-2) who was an obligate carrier; she had a family history of DMD and an affected son (II-4). The older sister gave birth to non-identical triplets and the boys were tested at six years old. One of them was affected and one was healthy; the girl was considered too young to be tested for carrier detection due to ethical issues.

\subsection{Quantitation of Serum Levels of MicroRNA-206 for Carrier Detection}

After the comparative analysis between carriers and non-carriers, miR-206 was enriched in the carriers group (Figure 3A). Serum levels of miR-206 are able to classify true DMD carriers and 
healthy females (Figure 3B), with an association criteria $>0.45$; with this number, the AUC in our study (Figure 3C) reached a value of 0.803 , a standard error (SE) of 0.065 , sensitivity $=78.26 \%$, and specificity $=70.83 \%$, with a $p$-value $<0.0001 *$, whereas the positive predictive value (PPV) was 78.26 and the negative predictive value (NPV) was 99.69 .

A)

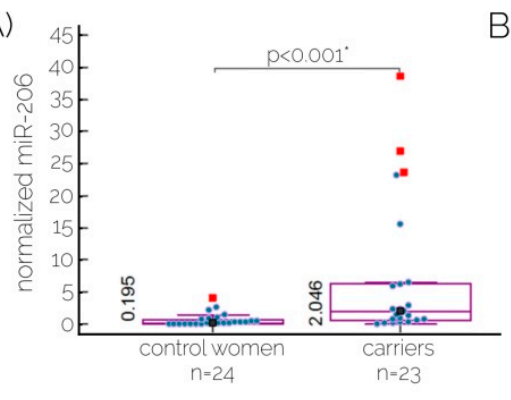

B)

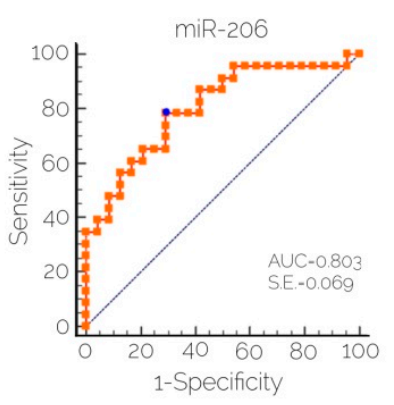

C)

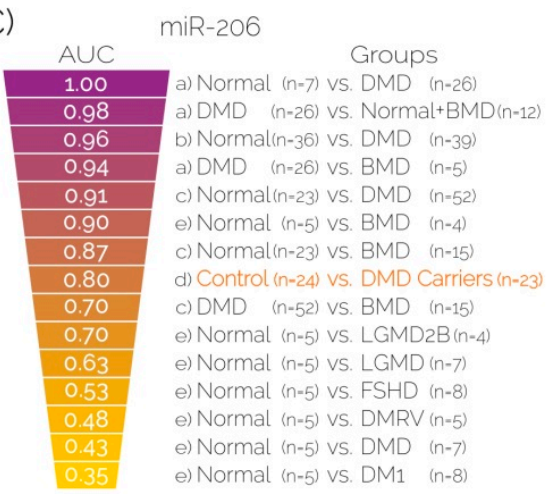

Figure 3. Serum levels of MicroRNA-206 for carrier detection. (A) Serum levels of miR-206 between DMD carriers and healthy females. The median levels are depicted with $(\bullet)$ and the horizontal lines bisecting the purple box plot show the interquartile range, individual values of samples are shown in $(\bullet)$. The most extreme values are indicated as ( $\mathbf{\square})$; (B) ROC (Receiver Operating Characteristic) curve for miR-206 to classify true DMD carriers, the optimal cut-off is indicated by (•); (C) Heat map of AUC (Area Under the Curve) values (best values are shown on top and purple) for miR-206 to classify different phenotypes reported by others (black text and lower-case letters) and the AUC of miR-206 obtained in our study (orange text, (d)) (a) [11]; (b)[23]; (c) [12]; (d) Present study and (e) [24].

\section{Discussion}

A general definition of a biomarker is: "A characteristic that is objectively measured and evaluated as an indicator of normal, pathogenic and biological processes or pharmacological responses to a therapeutic intervention" [25]. Therefore, research to identify non-invasive biomarkers for conditions such as dystrophinopathies is a growing field nowadays. In the specific case of DMD it has been shown that levels of miR-206 positively correlate with scores of the North Star Ambulatory Assessment (NSAA), which is an endpoint to evaluate the ability of DMD patients to perform common activities [26]. Therefore, biomarkers able to detect subtle changes among related phenotypes are of particular interest, as is the case of female carriers that present almost exclusive sub-clinical muscle involvement. The field of cell-free RNAs and specifically miRNAs has generated a growing interest, because some of these miRNAs reflect the physiological status of a disease from a non-invasive method of sampling [27]. Therefore, at least for carrier detection, miR-206 and other biomarkers present in serum are of utmost importance, since dystrophin abnormalities in muscle tissue of DMD carriers are not associated with clinical variables; only $26 \%$ of non-manifesting carriers have dystrophin-negative fibers in muscle biopsies [13] which are considered invasive. Therefore, the use of the "liquid biopsy" approach may potentially outperform the use of biopsies obtained directly from muscle tissue in DMD patients, but could probably gain more relevance for carrier detection.

According to Rao et al., tests for detecting true DMD carriers must satisfy the following conditions: (a) to be positive in affected boys; (b) to not produce false negative results; (c) testing carried out using a significant number of carriers and an equal number of age- and sex-matched controls; and (d) results should be compared with an established test [28]. In this regard, a recent study of proteomics explored proteins in 16 serum samples of asymptomatic DMD carriers showing that CA3 (Carbonic anhydrase III), MDH2 (Malate Dehydrogenase 2), MYL3 (Myosin Light Chain 3), ETFA (Electron Transfer Flavoprotein Alpha Subunit) and TNNT3 (Troponin T3, Fast Skeletal Type) proteins were decreased in females compared to DMD patients treated with steroids, [29]. In addition, m-calpain from 
platelets was recently proven useful for identifying true DMD carriers with $90 \%$ of informative tests [28], as well as other proteins such as GDF-8 (myostatin), AUC $=0.706$ ( $p=0.028$ ), and FSTN (follistatin), AUC $=0.877(p<0.0001)$ proposed by our group as biomarkers for carrier detection in DMD [30]. Nevertheless, the isolation of platelets for m-calpain detection is laborious and the ELISA technique for measuring protein concentrations may imply cross-reactivity antibody concerns for particular proteins. Therefore, herein we investigated, as an alternative, the possible use of miR-206 as a biomarker for carrier detection in DMD. Previous studies showed that miR-206 expression is muscle-specific, it is produced by myoblasts and correlates with disease progression in DMD [31], it distinguishes between DMD and BMD [12], and it increases when muscular damage occurs; therefore, miR-206 is thought to be linked to muscle repair [12,32]. Hence, we hypothesized that it may be increased in female DMD carriers. We explored the potential applicability of the isolation of miR-206 from human serum samples and its amplification by real-time PCR for carrier detection in DMD because, to our knowledge, this application was not previously explored. We did not find any correlation of miR-206 with age or body mass index (BMI) in any group. In addition, GDF-8 and FSTN did not correlate with miR-206 in this cohort. Interestingly, there were five cases with high levels of the microRNA within the carrier group, and these were all obligate carriers, but manifestations such as weakness were not reported by them, with the exception of the samples with the highest and the third-highest values of all. Those samples correspond to the mother of family 3 (Table 3) (with severe cardiac involvement) and her older daughter, the mother of the index case, a male children with a severe DMD phenotype who lost independent walking at five years old and needed assistance for walking at the age of four (the patient underwent steroid treatment for a short period of time). Cardiac involvement in the mother of the above-mentioned patient is still unknown.

Our data suggest that miR-206 allows the detection of DMD female carriers (who are, in most cases, asymptomatic), which demonstrates advantages over to $\mathrm{CK}$ as biomarker. For instance, $\mathrm{CK}$ decreases when muscle mass is highly diminished, even in male patients (advanced disease state) whose phenotype is more evident compared to females (usually asymptomatic), and it is altered by several conditions such as physical activity, race, age and gender [33]. In fact, CK provides a diagnostic efficiency $=50 \%[10], \mathrm{PPV}=100 \%, \mathrm{NPV}=33.3 \%$, specificity $=100 \%$, and sensitivity $=33.3 \%[10]$; the latter is lower than the sensitivity displayed by miR-206 (78.2\%) reported herein. Although further studies are required to confirm our findings (e.g., including larger cohorts with manifesting carriers), we demonstrated the utility of combining mini-STR assays and serum microRNAs as biomarkers to improve carrier detection and genetic counseling (Figure 4), especially in complex cases with unknown mutations and a negative family history.

In addition, our mini-STR assay allowed the amplification of multiple targets, and the study of alleles present in our population revealed the best markers for segregation analyses in Mexican families. It should be noted that best practices for genetic testing in DMD suggest that at least three DNA markers should be used to appropriately flank the gene [34], in order to avoid overlooking the recombination events that may affect genetic counseling when the location of the mutation is unknown (Figure 1). Agreeing with these recommendations, our assays included 10 loci evenly distributed along the gene, and smaller amplicons (mini-STRs) instead of the longer ones to improve the probabilities of success in analyzing highly degraded DNA samples. Most STR markers were highly polymorphic in the populations studied herein, suggesting a high level of informativeness of the markers, since the linkage between two variable loci is based on its heterozygosity. With this argument, it is widely known that there is high degree of substructure between Mexican populations that may underlie important biomedical phenotypes [16]. 


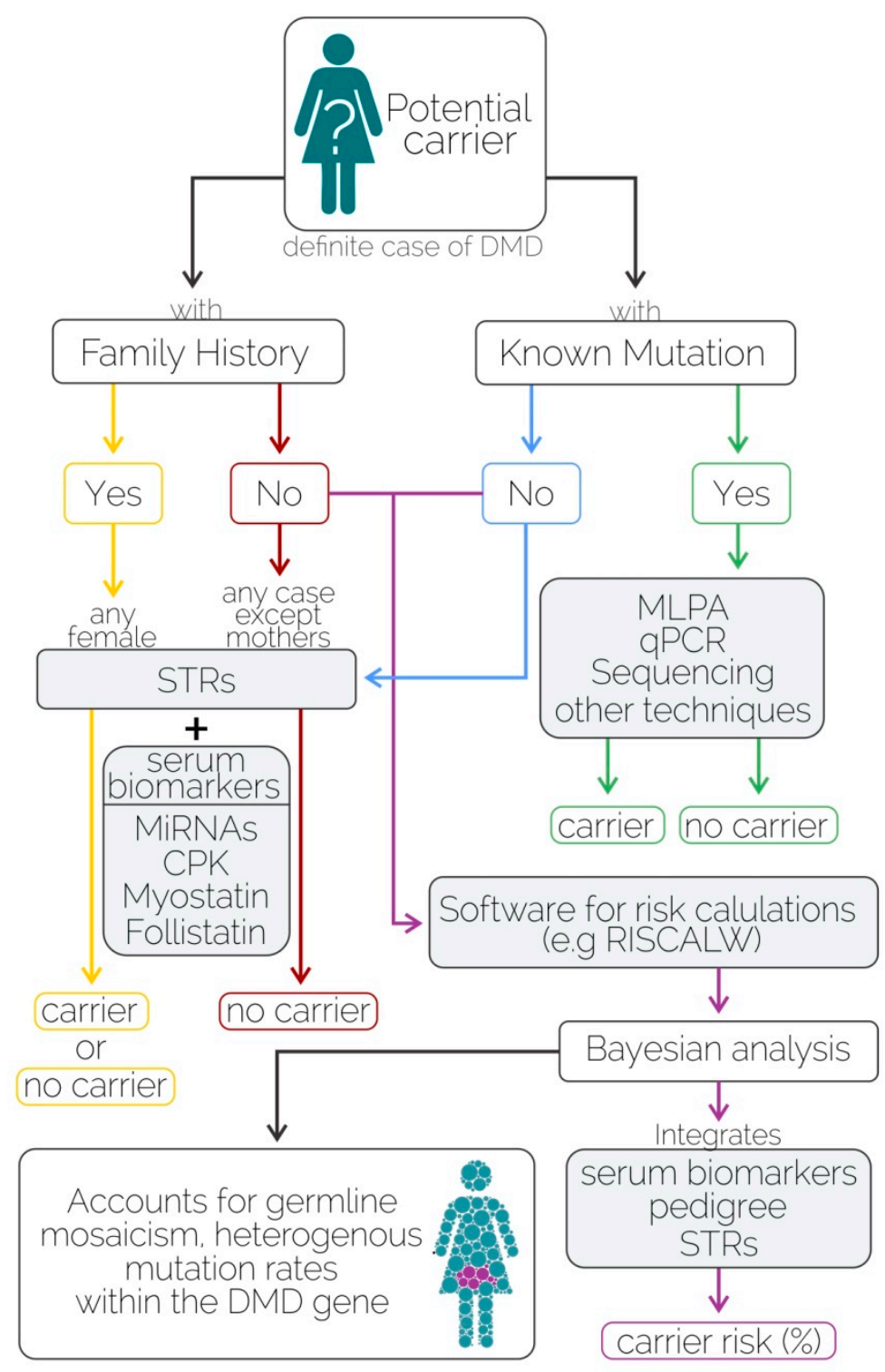

Figure 4. Algorithm for carrier detection using mini-STR assays and serum biomarkers.

Although recent publications regarding the "liquid biopsy" approach are mainly focused on cancer, the use of miR-206 obtained from the serum for carrier detection in DMD as the approach reported herein could be considered a clinical application of liquid biopsies to support the diagnosis of neuromuscular disorders such as DMD. The applicability of the mini-STR assays described in this work to amplify cell-free DNA requires further exploration, although other authors have previously shown the successful amplification of 19 STR markers from maternal plasma for NIPT using mini-STR assays [35].

Integration of the analysis of microRNAs and DNA markers may improve carrier detection and genetic counseling in DMD. Therefore, in the present work, new tools to improve carrier screening in DMD through "liquid biopsy" approach are proposed.

\section{Materials and Methods}

\subsection{Sampling, DNA Isolation and Quantification}

Potential carriers belonging to DMD families were referred to our laboratory between 2010 and 2015. All cases correspond to female relatives of a DMD patient diagnosed according to MD 
STARNET criteria [6]. Diagnosis was established considering patients clinical evaluation, which included proximal and/or distal weakness, positive Gowers maneuver, age at onset, CK levels and family history [30]. Written informed consent was obtained from all participants; this study was approved by the Institutional ethics and research committees. Control group had a mean age of $34.65 \pm 12.47$ (18 min-56 max) whereas the DMD carrier group showed a mean age of $40.77 \pm 13.79$ (17 min-86 max). There were no differences in age and BMI, between groups. Medical records of participants and clinical inspection included the following data: presence of endometriosis, cancer (any type), arthritis, active infections at the time of sample collection, osteoporosis/fractures, hepatitis and/or cirrhosis, positive cases were excluded of the analysis.

Nucleic acid isolation was performed as follows: Genomic DNA was extracted from $5 \mathrm{~mL}$ peripheral lymphocytes using the CTAB-DTAB method [36].

In order to gain insights regarding the allele diversity in our country, we analyzed Mexican population samples from different geographic regions, as follows: (1) North region ( $n=105)$, including individuals from Chihuahua, Sinaloa, and Sonora states; (2) West region $(n=101)$, represented by the Jalisco state; and (3) Southeast region $(n=131)$, including volunteers of the Yucatán state. A Nanodrop ND-1000 spectrophotometer (Thermo Fisher Scientific, Wilmington, DE, USA) was used to measure DNA sample concentration. One hundred and five ng of DNA were used to perform MLPA and STR assays, respectively. On the other hand, human serum samples from female relatives of patients underwent purification of total RNA including miRNA with the miRNeasy Mini Kit (OQIAGEN GmbH, Hilden, Germany).

\subsection{Mutation Detection by MLPA}

Genetic screening for copy number variations within the DMD gene was done in order to confirm carrier status using MLPA technique, according to manufacturer's instructions (P034/P035, MRC-Holland, Amsterdam, Netherlands). Data were analyzed using GeneMarker v1.91 software (@ 2016 SoftGenetics, LLC., State College, PA, USA) as previously described [37].

\subsection{Mini-STR Assay Design and Genotyping}

Primers were designed according to standard conditions for multiplex mini-STR assays, which are "reduced-size STR amplicons" that outperform conventional amplicons when amplifying degraded DNA [38]. Reverse primers were labeled with different fluorescent dyes. Conditions for each assay are shown in Table 4. DNA samples were genotyped for the markers: DXS1236, DI623, 5'-5n4, 5'-7n4, DXS1237, DXS997, DXSDMD-In60, DXSDMD-In30, DXS1242 y DXS1234 at the DMD, using fluorescent polymerase chain reaction (PCR) (Figure 1A). Standard cycling was performed in a thermal cycler (Bio-Rad Laboratories, Inc, Berkeley, CA, USA). STR genotypes were obtained by fluorescent capillary electrophoresis with the ABI 310 Genetic Analyzer (Applied Biosystems, Carlsbad, CA, USA). About $1.2 \mu \mathrm{L}$ of PCR product, $9 \mu \mathrm{L}$ of Hi-Di formamide (Applied Biosystems), and $0.3 \mu \mathrm{L}$ of Genescan-500 LIZ size standard (Applied Biosystems) were mixed and loaded into capillaries with POP-4 (Applied Biosystems) as separation matrix. Finally, alleles were assigned by GeneMarker HID Human STR Identity software (@ 2016 SoftGenetics, LLC., State College, PA, USA) (Figure 1B). 
Table 4. STR assay conditions for the 10 polymorphic microsatellite sites.

\begin{tabular}{|c|c|c|c|c|c|c|c|}
\hline \multirow[t]{2}{*}{ Marker } & \multirow[t]{2}{*}{ Locus } & \multirow[t]{2}{*}{ Primer Sequences $\left(5^{\prime} \rightarrow 3^{\prime}\right)$} & \multirow[t]{2}{*}{ Fluorophore } & \multirow[t]{2}{*}{ PCR Product (bp) } & \multicolumn{3}{|c|}{$\begin{array}{l}\text { Conditions for Multiplex } \\
\text { STRs Assays PCR }\end{array}$} \\
\hline & & & & & Denaturation & Annealing & Extension \\
\hline DX997 & Intron 48 & $\begin{array}{l}\text { AGCTGGCTTTATTTTAAGAGGACA } \\
\text { GGGTAGCCTTCCAAGAATAGG }\end{array}$ & FAM & 88 & \multirow{2}{*}{$95^{\circ} \mathrm{C}, 25 \mathrm{~s}$} & \multirow{2}{*}{$64^{\circ} \mathrm{C}, 30 \mathrm{~s}$} & \multirow{2}{*}{$72{ }^{\circ} \mathrm{C}, 30 \mathrm{~s}$} \\
\hline DXS1237 & Intron 45 & $\begin{array}{l}\text { GGCTATAATTCTTTAACTTTGGCAAG } \\
\text { CСАССТСТTTCССТСТT }\end{array}$ & $F A M$ & 169 & & & \\
\hline DXS1236 & Intron 49 & $\begin{array}{l}\text { CGTTTACCAGCTCAAAATCTCAAC } \\
\text { GGCTTTGGCCATACAGAAAA }\end{array}$ & PET & 111 & \multirow{4}{*}{$95^{\circ} \mathrm{C}, 18 \mathrm{~s}$} & \multirow{4}{*}{$62.5^{\circ} \mathrm{C}, 20 \mathrm{~s}$} & \multirow{4}{*}{$72{ }^{\circ} \mathrm{C}, 15 \mathrm{~s}$} \\
\hline DI623 & Intron 62 & $\begin{array}{c}\text { CGAGACACCCCACCTCTG } \\
\text { GCCATGGTGAATGATCAGAAA }\end{array}$ & FAM & 140 & & & \\
\hline $5^{\prime}-5 n 4$ & Intron 4 & $\begin{array}{l}\text { GAGAGAAGGGAAAATGATGAATAAAA } \\
\text { TGTCAGAACTTTGTCACCTGTCTT }\end{array}$ & VIC & 148 & & & \\
\hline $5^{\prime}-7 \mathrm{n} 4$ & Intron 25 & $\begin{array}{l}\text { CTTTTAAGGCAGTTGGTGAAGC } \\
\text { TCCAGGATCCAACAATATCTCA }\end{array}$ & PET & 181 & & & \\
\hline DXSDMD-In30 & Intron 30 & $\begin{array}{c}\text { GTTAGTCCCTATTCTATTCCTTTC } \\
\text { AAGAATGCCACCAAAATGAC }\end{array}$ & PET & 162 & \multirow[b]{2}{*}{$95^{\circ} \mathrm{C}, 30 \mathrm{~s}$} & \multirow[b]{2}{*}{$57^{\circ} \mathrm{C}, 40 \mathrm{~s}$} & \multirow[b]{2}{*}{$72{ }^{\circ} \mathrm{C}, 30 \mathrm{~s}$} \\
\hline DXSDMD-In60 & Intron 60 & $\begin{array}{l}\text { CGAGGGGATCAGGGTAATA } \\
\text { CTGTTCTCTTCTCTGGTCATCA }\end{array}$ & $N E D$ & 136 & & & \\
\hline DXS1234 & Region $3^{\prime}$ & $\begin{array}{c}\text { CTGTTTGCGACATTGGCTAT } \\
\text { GCAAACATCATGGTGATAACTGA }\end{array}$ & VIC & 151 & $95^{\circ} \mathrm{C}, 20 \mathrm{~s}$ & $57^{\circ} \mathrm{C}, 40 \mathrm{~s}$ & $72^{\circ} \mathrm{C}, 30 \mathrm{~s}$ \\
\hline DXS1242 & Region $5^{\prime}$ & $\begin{array}{l}\text { CAAAAATCAAATGGAAGTAGAATAGC } \\
\text { TCGCTATTCTGAAATAGTGTTTTCC }\end{array}$ & $N E D$ & 112 & $95^{\circ} \mathrm{C}, 30 \mathrm{~s}$ & $59^{\circ} \mathrm{C}, 50 \mathrm{~s}$ & $72{ }^{\circ} \mathrm{C}, 40 \mathrm{~s}$ \\
\hline
\end{tabular}




\subsection{Quantitation of MicroRNAs by Real Time PCR}

MicroRNAs were isolated from $200 \mu \mathrm{L}$ of human serum samples of participants using @QIAGEN ${ }^{\circledR}$ miRNeasy kit following manufacturer's instructions. The amount of total RNA was measured with a Nanodrop ND-1000 spectrophotometer (Thermo Fisher Scientific, Wilmington, DE USA). Using microRNAs as templates, cDNA was synthesized and amplified using TaqMan MicroRNA assay for miR-206 (dystromir) and miR-223* (granulocyte-specific) (Applied Biosystems ${ }^{\circledR}$ ); the last one was used as endogenous control, as previously reported [11]. Relative quantitation of both probes (miR-206 and miR-223*) was performed in a LightCycler ${ }^{\circledR} 480$ II (Roche, GmbH, Mannheim, Germany). Normalization was performed using Pfaffl method [39] considering true efficiency of each reaction, which is derived from serial dilutions of the target (miR-206, Efficiency, $(\mathrm{E})=1.845$, detection limits $\left.0.18-1.8 \times 10^{-3} \mathrm{ng} / \mu \mathrm{L}\right)$ and reference gene $\left(\mathrm{miR}-223^{*} \mathrm{E}=2.136\right.$, detection limits $0.18-1.8 \times 10^{-4} \mathrm{ng} / \mu \mathrm{L}$ ). Results were automatically calculated from the $\mathrm{Cp}$ values (detection threshold point) of the target and the reference amplicons.

\subsection{Statistical Analysis}

Allele frequencies and genetic diversity parameters represented by heterozygosity and PIC were estimated for each locus with the Excel spreadsheet Powerstats [40]. Exact tests to check HWE agreement for each locus were carried out using the Arlequin software [41]. This assessment was adjusted for multiple comparisons using Bonferroni correction. Values of miR-206 were tested for normality by the Shapiro-Wilk test. Statistically significant differences among experimental groups (between median values of each group) were analyzed by the Mann-Whitney $U$ test since were non-normally distributed.

Acknowledgments: We thank all participants and financing from Fondos Sectoriales CONACYT 2015 project 262150 (young researcher grant) and we also thank the E015 program ISSSTE for supporting research. We acknowledge the funding of Administración del Patrimonio de la Beneficencia Pública/Ministry of Health provided to ADMO A.C. project 2016. We also thank MSc. Victor Martínez-Sevilla for technical assistance, Ikuri Alvarez Maya for suggestions and Dulce Jimenez for infographic design.

Author Contributions: Mónica Alejandra Anaya-Segura performed MicroRNA experiments, mini-STR amplification, initial statistical analysis and helped write the article, Héctor Rangel-Villalobos performed statistical analysis, sample collection and critically reviewed the manuscript, Gabriela Martínez-Cortés designed the mini-STR assay and performed statistical analysis, Benjamín Gómez-Díaz performed the MLPA test and analysis, Ramón Mauricio Coral-Vázquez planned the microRNA experiments, analyzed data and critically reviewed the manuscript, Edgar Oswaldo Zamora-González performed sample isolation and critically reviewed the manuscript, Silvia García reviewed and supervised clinical data and Luz Berenice López-Hernández planned the experimental work, supervised and coordinated the group and wrote the paper. All authors read and approved the final version of the work.

Conflicts of Interest: The authors declare no conflict of interest.

\section{References}

1. Muntoni, F.; Torelli, S.; Ferlini, A. Dystrophin and mutations: One gene, several proteins, multiple phenotypes. Lancet Neurol. 2003, 2, 731-740. [CrossRef]

2. Lopez-Hernandez, L.B.; Ayala-Madrigal, M.L.; van Heusden, D.; Estrada-Mena, F.J.; Canto, P.; Sandoval-Ramirez, L.; Gomez-Diaz, B.; Coral-Vazquez, R.M. [Improvements in the diagnosis of dystrophinopathies: What have we learnt in these last 20 years?]. Revista de Neurologia 2011, 52, $239-249$. [PubMed]

3. Imbornoni, L.; Price, E.T.; Andrews, J.; Meaney, F.J.; Ciafaloni, E.; Cunniff, C. Diagnostic and clinical characteristics of early-manifesting females with duchenne or becker muscular dystrophy. Am. J. Med. Genet. A 2014, 164A, 2769-2774. [CrossRef] [PubMed]

4. Mavrogeni, S.; Bratis, K.; Papavasiliou, A.; Skouteli, E.; Karanasios, E.; Georgakopoulos, D.; Kolovou, G.; Papadopoulos, G. Cmr detects subclinical cardiomyopathy in mother-carriers of duchenne and becker muscular dystrophy. JACC Cardiovasc. Imaging 2013, 6, 526-528. [CrossRef] [PubMed] 
5. Mercier, S.; Toutain, A.; Toussaint, A.; Raynaud, M.; de Barace, C.; Marcorelles, P.; Pasquier, L.; Blayau, M.; Espil, C.; Parent, P.; et al. Genetic and clinical specificity of 26 symptomatic carriers for dystrophinopathies at pediatric age. Eur. J. Hum. Genet. 2013, 21, 855-863. [CrossRef] [PubMed]

6. Mathews, K.D.; Cunniff, C.; Kantamneni, J.R.; Ciafaloni, E.; Miller, T.; Matthews, D.; Cwik, V.; Druschel, C.; Miller, L.; Meaney, F.J.; et al. Muscular dystrophy surveillance tracking and research network (md starnet): Case definition in surveillance for childhood-onset duchenne/becker muscular dystrophy. J. Child. Neurol. 2010, 25, 1098-1102. [CrossRef] [PubMed]

7. Giliberto, F.; Ferreiro, V.; Massot, F.; Ferrer, M.; Francipane, L.; Szijan, I. Prenatal diagnosis of duchenne/becker muscular dystrophy by short tandem repeat segregation analysis in argentine families. Muscle Nerve 2011, 43, 510-517. [CrossRef] [PubMed]

8. Fischer, C.; Kruger, J.; Gross, W. Riscalw: A windows program for risk calculation in families with duchenne muscular dystrophy. Ann. Hum. Genet. 2006, 70, 249-253. [CrossRef] [PubMed]

9. Grubwieser, P.; Muhlmann, R.; Berger, B.; Niederstatter, H.; Pavlic, M.; Parson, W. A new "ministr-multiplex" displaying reduced amplicon lengths for the analysis of degraded DNA. Int. J. Legal. Med. 2006, 120, 115-120. [CrossRef] [PubMed]

10. Hashim, R.; Shaheen, S.; Ahmad, S.; Sattar, A.; Khan, F.A. Comparison of serum creatine kinase estimation with short tandem repeats based linkage analysis in carriers and affected children of duchenne muscular dystrophy. J. Ayub Med. Coll. Abbottabad 2011, 23, 125-128. [PubMed]

11. Cacchiarelli, D.; Legnini, I.; Martone, J.; Cazzella, V.; D’Amico, A.; Bertini, E.; Bozzoni, I. Mirnas as serum biomarkers for duchenne muscular dystrophy. EMBO Mol. Med. 2011, 3, 258-265. [CrossRef] [PubMed]

12. Li, X.; Li, Y.; Zhao, L.; Zhang, D.; Yao, X.; Zhang, H.; Wang, Y.C.; Wang, X.Y.; Xia, H.; Yan, J.; et al. Circulating muscle-specific mirnas in duchenne muscular dystrophy patients. Mol. Ther. Nucleic Acids 2014, 3, e177. [CrossRef] [PubMed]

13. Hoogerwaard, E.M.; Ginjaar, I.B.; Bakker, E.; de Visser, M. Dystrophin analysis in carriers of duchenne and becker muscular dystrophy. Neurology 2005, 65, 1984-1986. [CrossRef] [PubMed]

14. Cai, X.; Janku, F.; Zhan, Q.; Fan, J.B. Accessing genetic information with liquid biopsies. Trends Genet. 2015, 31, 564-575. [CrossRef] [PubMed]

15. Rubi-Castellanos, R.; Martinez-Cortes, G.; Munoz-Valle, J.F.; Gonzalez-Martin, A.; Cerda-Flores, R.M.; Anaya-Palafox, M.; Rangel-Villalobos, H. Pre-hispanic mesoamerican demography approximates the present-day ancestry of mestizos throughout the territory of mexico. Am. J. Phys. Anthropol. 2009, 139, 284-294. [CrossRef] [PubMed]

16. Moreno-Estrada, A.; Gignoux, C.R.; Fernandez-Lopez, J.C.; Zakharia, F.; Sikora, M.; Contreras, A.V.; Acuna-Alonzo, V.; Sandoval, K.; Eng, C.; Romero-Hidalgo, S.; et al. Human genetics. The genetics of mexico recapitulates native american substructure and affects biomedical traits. Science 2014, 344, 1280-1285. [CrossRef] [PubMed]

17. Feener, C.A.; Boyce, F.M.; Kunkel, L.M. Rapid detection of ca polymorphisms in cloned DNA: Application to the 5' region of the dystrophin gene. Am. J. Hum. Genet. 1991, 48, 621-627. [PubMed]

18. King, S.C.; Roche, A.L.; Passos-Bueno, M.R.; Takata, R.; Zatz, M.; Cockburn, D.J.; Seller, A.; Stapleton, P.M.; Love, D.R. Molecular characterization of further dystrophin gene microsatellites. Mol. Cell. Probes 1995, 9, 361-370. [CrossRef]

19. Sun, R.F.; Zhu, Y.S.; Feng, J.L.; Tian, Z.; Kuang, W.J.; Liu, Y.; Zhang, H.B.; Li, S.B. Polymorphisms of three new microsatellite sites of the dystrophin gene. Genet. Mol. Res. 2011, 10, 744-751. [CrossRef] [PubMed]

20. Clemens, P.R.; Fenwick, R.G.; Chamberlain, J.S.; Gibbs, R.A.; de Andrade, M.; Chakraborty, R.; Caskey, C.T. Carrier detection and prenatal diagnosis in duchenne and becker muscular dystrophy families, using dinucleotide repeat polymorphisms. Am. J. Hum. Genet. 1991, 49, 951-960. [PubMed]

21. Dib, C.; Faure, S.; Fizames, C.; Samson, D.; Drouot, N.; Vignal, A.; Millasseau, P.; Marc, S.; Hazan, J.; Seboun, E.; et al. A comprehensive genetic map of the human genome based on 5,264 microsatellites. Nature 1996, 380, 152-154. [CrossRef] [PubMed]

22. Matsumoto, T.; Niikawa, N. Eight novel microsatellite markers in the $3^{\prime}$ region of the dystrophin gene useful for diagnosis of duchenne muscular dystrophy. Prenat. Diagn. 2004, 24, 1014-1015. [CrossRef] [PubMed]

23. Hu, J.; Kong, M.; Ye, Y.; Hong, S.; Cheng, L.; Jiang, L. Serum miR-206 and other muscle-specific micrornas as non-invasive biomarkers for duchenne muscular dystrophy. J. Neurochem. 2014, 129, 877-883. [CrossRef] [PubMed] 
24. Matsuzaka, Y.; Kishi, S.; Aoki, Y.; Komaki, H.; Oya, Y.; Takeda, S.; Hashido, K. Three novel serum biomarkers, miR-1, miR-133a, and miR-206 for limb-girdle muscular dystrophy, facioscapulohumeral muscular dystrophy, and becker muscular dystrophy. Environ. Health Prev. Med. 2014, 19, 452-458. [CrossRef] [PubMed]

25. Aartsma-Rus, A.; Ferlini, A.; Vroom, E. Biomarkers and surrogate endpoints in duchenne: Meeting report. Neuromuscul. Disord. 2014, 24, 743-745. [CrossRef] [PubMed]

26. Mazzone, E.; Martinelli, D.; Berardinelli, A.; Messina, S.; D’Amico, A.; Vasco, G.; Main, M.; Doglio, L.; Politano, L.; Cavallaro, F.; et al. North star ambulatory assessment, 6-minute walk test and timed items in ambulant boys with duchenne muscular dystrophy. Neuromuscul. Disord.: NMD 2010, 20, 712-716. [CrossRef] [PubMed]

27. Larrea, E.; Sole, C.; Manterola, L.; Goicoechea, I.; Armesto, M.; Arestin, M.; Caffarel, M.M.; Araujo, A.M.; Araiz, M.; Fernandez-Mercado, M.; et al. New concepts in cancer biomarkers: Circulating mirnas in liquid biopsies. Int. J. Mol. Sci. 2016, 17, 627. [CrossRef] [PubMed]

28. Rao, M.V.; Sindhav, G.M.; Mehta, J.J. Duchenne/becker muscular dystrophy: A report on clinical, biochemical, and genetic study in gujarat population, india. Ann. Indian Acad. Neurol. 2014, 17, 303-307. [CrossRef] [PubMed]

29. Ayoglu, B.; Chaouch, A.; Lochmuller, H.; Politano, L.; Bertini, E.; Spitali, P.; Hiller, M.; Niks, E.H.; Gualandi, F.; Ponten, F.; et al. Affinity proteomics within rare diseases: A bio-nmd study for blood biomarkers of muscular dystrophies. EMBO Mol. Med. 2014, 6, 918-936. [CrossRef] [PubMed]

30. Anaya-Segura, M.A.; Garcia-Martinez, F.A.; Montes-Almanza, L.A.; Diaz, B.G.; Avila-Ramirez, G.; Alvarez-Maya, I.; Coral-Vazquez, R.M.; Mondragon-Teran, P.; Escobar-Cedillo, R.E.; Garcia-Calderon, N.; et al. Non-invasive biomarkers for duchenne muscular dystrophy and carrier detection. Molecules 2015, 20, 11154-11172. [CrossRef] [PubMed]

31. Zaharieva, I.T.; Calissano, M.; Scoto, M.; Preston, M.; Cirak, S.; Feng, L.; Collins, J.; Kole, R.; Guglieri, M.; Straub, V.; et al. Dystromirs as serum biomarkers for monitoring the disease severity in duchenne muscular dystrophy. PLoS ONE 2013, 8, e80263. [CrossRef] [PubMed]

32. Ma, G.; Wang, Y.; Li, Y.; Cui, L.; Zhao, Y.; Zhao, B.; Li, K. MiR-206, a key modulator of skeletal muscle development and disease. Int. J. Biol. Sci. 2015, 11, 345-352. [CrossRef] [PubMed]

33. Baird, M.F.; Graham, S.M.; Baker, J.S.; Bickerstaff, G.F. Creatine-kinase- and exercise-related muscle damage implications for muscle performance and recovery. J. Nutr. Metab. 2012, 2012, 13. [CrossRef] [PubMed]

34. Abbs, S.; Tuffery-Giraud, S.; Bakker, E.; Ferlini, A.; Sejersen, T.; Mueller, C.R. Best practice guidelines on molecular diagnostics in duchenne/becker muscular dystrophies. Neuromuscul. Disord.: NMD 2010, 20, 422-427. [CrossRef] [PubMed]

35. Aghanoori, M.R.; Vafaei, H.; Kavoshi, H.; Mohamadi, S.; Goodarzi, H.R. Sex determination using free fetal DNA at early gestational ages: A comparison between a modified mini-str genotyping method and real-time pcr. Am. J. Obstet. Gynecol. 2012, 207, 202.e1-202.e8. [CrossRef] [PubMed]

36. Gustincich, S.; Manfioletti, G.; del Sal, G.; Schneider, C.; Carninci, P. A fast method for high-quality genomic DNA extraction from whole human blood. Biotechniques 1991, 11, 298-300, 302. [PubMed]

37. Lopez-Hernandez, L.B.; Gomez-Diaz, B.; Luna-Angulo, A.B.; Anaya-Segura, M.; Bunyan, D.J.; Zuniga-Guzman, C.; Escobar-Cedillo, R.E.; Roque-Ramirez, B.; Ruano-Calderon, L.A.; Rangel-Villalobos, H.; et al. Comparison of mutation profiles in the duchenne muscular dystrophy gene among populations: Implications for potential molecular therapies. Int. J. Mol. Sci. 2015, 16, 5334-5346. [CrossRef] [PubMed]

38. Butler, J.M. Constructing str multiplex assays. Methods Mol. Biol. 2005, 297, 53-66. [PubMed]

39. Pfaffl, M.W. Quantification Strategies in Real-Time pcr.; Bustin, S.A., Ed.; International University Line: La Jolla, CA, USA, 2002.

40. Tereba, A. Tools for Analysis of Population Statistics; Promega Corporation: Fitchburg, WI, USA, 1999; pp. 14-16.

41. Excoffier, L.; Lischer, H.E. Arlequin suite ver 3.5: A new series of programs to perform population genetics analyses under linux and windows. Mol. Ecol. Resour. 2010, 10, 564-567. [CrossRef] [PubMed]

(C) 2016 by the authors; licensee MDPI, Basel, Switzerland. This article is an open access article distributed under the terms and conditions of the Creative Commons Attribution (CC-BY) license (http://creativecommons.org/licenses/by/4.0/). 